\section{PRÓBA FORMALNEJ DEFINICJI DOBROBYTU}

ŚLĄSKI

PRZEGLĄD

STATYSTYCZNY

Nr 13(19)

\author{
Janusz Łyko, Antoni Smoluk
}

Uniwersytet Ekonomiczny we Wrocławiu

ISSN 1644-6739

e-ISSN 2449-9765

DOI: $10.15611 /$ sps.2015.13.02

Streszczenie: Dobrobyt jest jakością i podobnie jak każda jakość ma trzy naturalne stany: mało, średnio, dużo. $Z$ dobrobytem jest jak ze szczęściem, czy zdrowiem: żyjąc w dobrobycie, zwykle nie zdajemy sobie z tego sprawy. Oczywiście wszyscy chcemy żyć w dobrobycie. I tak jak pojęcia szczęścia nie precyzujemy, by nie zapeszyć i unikamy afiszowania się nim, tak samo czynimy z dobrobytem. Jest to błogosławiony stan współżycia z przyrodą i ludźmi. Dobrobyt trwały jest traktowany jako dobrobyt stabilny. Jest on możliwy tylko w społeczeństwie tradycyjnym, w którym każdy wie, co ma robić i robi to sumiennie. Dobrobyt wiąże się też z darwinizmem społecznym; populacja jest w dobrobycie, gdy wzrasta wykładniczo. Równanie Malthusa

$$
y^{\prime}=p y
$$

można traktować jako ścisłą definicję dobrobytu. Dobrobyt to pojęcie holistyczne, tyczące się całej społeczności, jest jakością życia, często utożsamianą ze stopą życiową. Na bezludnej wyspie nie ma dobrobytu. Dobrobyt jest związany z wydajnością pracy i oznacza większą efektywność ekonomii niż potrzeby społeczności. Można również dobrobyt określać przez funkcje użyteczności. Średnia użyteczność populacji definiuje dobrobyt społeczny. Z każdą funkcją użyteczności związana jest preferencja. Jeśli profil populacji spełnia regułę $2 / 3$, to wtedy relacja maksymalna jest preferencją; ta właśnie preferencja jest dobrobytem społecznym. Stabilność zaś dobrobytu jest opisana za pomocą macierzy przejść Markowa

$$
M=\left(\begin{array}{ccc}
\frac{2}{3} & \frac{1}{3} & 0 \\
\frac{1}{3} & \frac{1}{3} & \frac{1}{3} \\
0 & \frac{1}{3} & \frac{2}{3}
\end{array}\right)
$$

ze stanu: niski byt, byt, dobry byt, kolejno do tychże stanów. Jeśli prawdopodobieństwa przejść są takie jak w macierzy M, to w stanie granicznym populacja dzieli się na równe trzy części. Zawsze są biedni, ludzie normalni, czyli szczęśliwi, i wreszcie bogaci. Za dobrobyt można też uważać stan ekonomii - koszyk dóbr, w którym globalna funkcja użyteczności osiąga maksimum. Dobrobyt jest niewątpliwie związany z organizacją pracy i koniunkturą. Cały obecny świat żyje w dobrobycie, bowiem bogactwo świata od 2000 roku podwoiło się i w 2013 roku mierzy 263 biliony dolarów amerykańskich. Zasoby rosną więc wykładniczo. Należy jednak pamiętać o liliach polnych i ich wyglądzie, o ptakach niebieskich i ich trosce o byt. Pojęcie dobrobytu jest bardziej natury duchowej niż materialnej. Daremnie późno kładziesz się spać i wcześniej wstajesz - swoją troską niewiele wskórasz. Bóg bowiem i we śnie obdarza umiłowanego swego.

Fryderyk Nietzsche uważał życie za jedyną wartość. Byt jest wszystkim dobrem, a niebyt jest złem. Jeśli istniejesz, jesteś w dobrobycie. Nie ma dobrobytu bez równowagi i pełnego zatrudnienia. Mierzyć dobrobyt można indeksem 


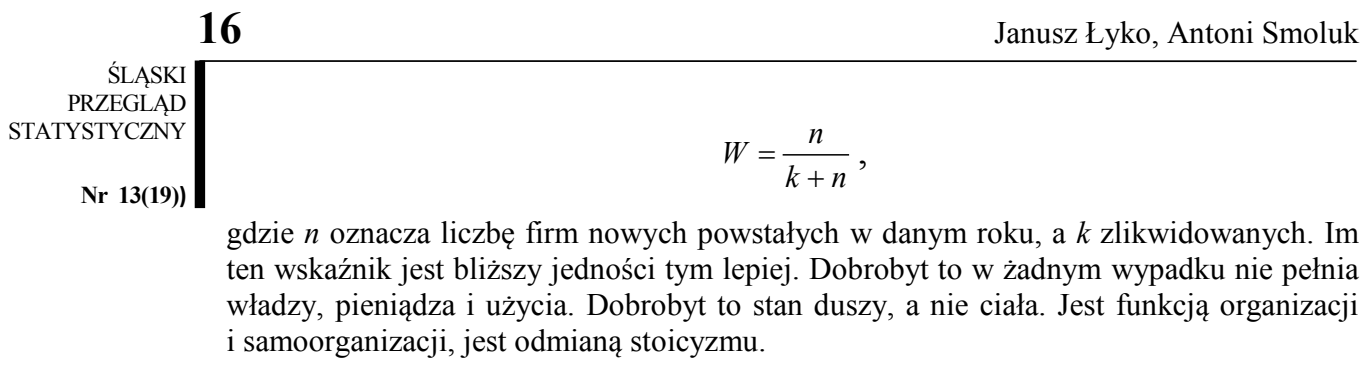

Słowa kluczowe: dobrobyt, reguła $2 / 3$, funkcja użyteczności, wzrost naturalny, macierz Markowa.

Czym jest dobrobyt? Jest wiele różnych - nawet nieporównywalnych - definicji tego pojęcia. Definicje te są zwykle opisowe, w związku z czym nie wiadomo, jak mierzyć dobrobyt. Geograficzne pojęcie linii wiecznego śniegu jest ściśle określonym stanem fizycznym. W ekonomii operuje się linią ubóstwa, jednak takiej definicji jak geograficzna nie ma; nie ma, ponieważ nie wiemy czym jest ubóstwo. Wydaje się, że ubóstwo jest takim stanem majątkowym, w którym nie ma oszczędności, czyli brak jest inwestycji. Pojęcie dobrobytu konotuje się ze stabilnością gdyż nie ma dobrobytu bez poczucia bezpieczeństwa. Dobrobyt wiąże się zwykle ze sprawiedliwością i równością - tak nauczają socjaliści. Jednak tak naprawdę dobrobyt nie ma nic wspólnego z równością. Do pomiaru koncentracji bogactwa używa się krzywej Lorenza i współczynnika Giniego. W niniejszym eseju zostało zaproponowane zastosowanie reguły $2 / 3$ do definicji bogactwa. Reguła ta wiąże się z naturalnym podziałem każdej populacji na trzy części równoprawdopodobne: niski, normalny i wysoki poziom nasycenia. Dziś przez dobrobyt rozumie się stan wysokiego zaspokojenia potrzeb bytowych i kulturalnych ludności. Jest to definicja typu marksistowskiego obowiązująca $\mathrm{w}$ czasach przejściowych trudności w zaopatrzeniu. Za miernik dobrobytu uważa się wielkość dochodu narodowego na mieszkańca. Dobrobyt jest jakąś preferencją i tej preferencji chcemy szukać, korzystając z reguły $2 / 3$. Czy linia ubóstwa pokrywa się z pierwszą tercjaną rozkładu bogactwa? Populacja jest w dobrobycie stabilnym, gdy macierz Markowa przejść ze stanu do stanu jest podanym dalej operatorem $T$.

Całość to cecha, a więc przymiot. Analogonem mediany niech będą dwie tercjany - mała i wielka. Są to kwantyle dzielące rozkład na wspomniane trzy klasy równoprawdopodobne: lewą o niskim natężeniu cechy, środkową o normalnym i prawą o dużym. Oczywiście, dla ułatwienia, mówimy tu o rozkładzie ciągłym; z tego właśnie powodu w każdej klasie jest $\frac{1}{3}$ populacji mierzonej rozkładem. Podziały takie 
można dalej robić; otrzymuje się wtedy drobniejsze rozbicia, bardziej szczegółowe, niemal jednorodne. Ternarny podział jest skutkiem działania doboru naturalnego i zasady równowagi. Różnorodność jest STATYSTYCZNY oznaką oddziaływania wielu czynników.

Marie-Jean-Antoine Marquis de Condorcet jako pierwszy zajmował się preferencjami i wyborem społecznym. Twierdził, że celem ludzkości jest opanowanie przyrody i maksymalne spełnienie marzenia człowieka o powszechnej radości i bezgranicznym szczęściu. Jednocześnie pokazywał, że nie ma jednoznacznie określonej preferencji grupowej. Dopiero reguła $2 / 3$ adekwatnie rozwiązuje problem grupowego wyboru.

Społeczeństwo średniowieczne to trzy stany społeczne; bardzo trudna, wręcz prawie niemożliwa, była zmiana pozycji w tej zastygłej hierarchicznej strukturze społecznej. Macierz Markowa przejść ze stanu do stanu jest tu macierzą jednostkową: trzy jedynki na przekątnej i same zera: w klasie, w której się urodziłeś, pozostaniesz już do śmierci.

"Ubogich zawsze mieć będziecie” - są to słowa Jezusa (Ewangelia św. Jana 12.8). Ubóstwo jest sposobem życia. Zwalczanie ubóstwa jest działaniem sprzecznym z naturą. Część populacji musi być uboga, bo wynika to $\mathrm{z}$ uwarunkowań biologicznych Ubóstwo jest postawą życiową, zalecaną przez wyznawaną religię lub filozofię, jest sposobem na życie. Znany dowcip z serii pytań do radia Erywań pięknie objaśnia naturę bogactwa - „Czy w komunizmie będą środki płatnicze? - Doktrynerzy mówią, że nie będą, rewizjoniści, że będą, a my prawdziwi marksiści-leniniści odpowiadamy, że u jednych będą, a u innych nie będą". W każdej populacji są zawsze niscy, średni i wysocy; w każdej populacji są szczupli, normalnie zbudowani i otyli. Zwalczanie ubóstwa to próba przemiany natury ludzkiej. A może właśnie jakość życia ubogich jest najwyższa? Avaro omnia desunt, sapienti nihil - chciwemu wszystkiego brakuje, mądremu niczego. Znaczy to tyle: pozbądź się pragnień, a będziesz bogaty i szczęśliwy. Brak pożądań oznacza 100\% satysfakcji [Dębek 2014]. Najlepszy jest pierwszy łyk piwa, najsmaczniejsze są wstępne kęsy, gdyż wraz ze wzrostem ilości użyteczność dóbr maleje.

Każda jakość ma trzy poziomy intensywności, każdy przymiotnik ma trzy stopnie. Tercjany są fundamentalnymi i naturalnymi kwantylami dzielącymi populację na trzy części (rys. 1). Ten podział jest podstawą reguły $2 / 3$, która wyklucza średnie częstotliwości. Jeżeli częstotliwość decyzji jest ostro większa od $\frac{1}{3}$, to jest również ostro 
większa od $\frac{2}{3}$. Analogonem kalibracji rozkładu przez tercjany jest

Nr 13(19)) ternarny podział czasu - ideał, o który walczono latami, a który stał się możliwy jedynie w warunkach wysokiej wydajności pracy. Dobę dzielimy na trzy równe części: sen -8 godzin, praca -8 godzin i 8 godzin rozrywki (rys. 2). Jest to rewolucja, która uformowała dzisiejszy świat. Krótki, ośmiogodzinny dzień pracy jest oznaką powszechnego dobrobytu. Podział doby na trzy równe części upamiętniono w Melbourne pomnikiem, będącym to jednocześnie monumentem dobrobytu, w którym mamy szczęście żyć. Charles Le Corbusier i koledzy-urbaniści, podzielili miasto na części odpowiadające podziałowi czasu: dzielnica pracy, dzielnica rozrywki i dzielnica snu. Nieszczęściem jednakże okazał się zanik potrzeb duchowych: ludzkość zadowala się chlebem i wyścigami. Rys. 2 pokazuje, że czas ma naturę kolistą: czas powraca - bogactwo topnieje. Ostatnie zdanie streszcza teorię inflacji. Inflacja odzwierciedla malejącą stopę zysku, spadek wartości kapitału oraz naturalną skłonność ludzi do bogacenia się - dzisiejszy utarg nie może być niższy od wczorajszego, lepszy towar chce się sprzedać drożej. Inflacja jest specyficznym dążeniem układu rynkowego do równowagi. Ceny zbyt duże nie spadają, a tylko te zbyt niskie idą w górę. Wzrost wydajności jest źródłem inflacji, gdyż prowadzi do nadzwyczajnych zysków, które inflacja redukuje. Inflacja jest więc naturalnym produktem rozwoju gospodarczego.

\begin{tabular}{rrrrl} 
Źle & & Normalnie & & Dobrze \\
\hline Mało & $T_{0}$ & Średnio & $T_{1}$ & Dużo
\end{tabular}

Rys. 1. Tercjany - fundamentalne kwantyle

Źródło: opracowanie własne.

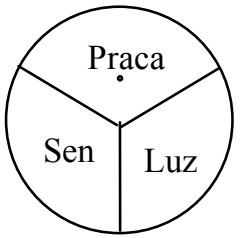

Rys. 2. Podział doby - tercjany czasowe

Źródło: opracowanie własne.

Zbiór małej tercjany to ten fragment populacji, w którym zmienna losowa nie przekracza tej właśnie tercjany. Zgodność - równość $\mathrm{z}$ dokładnością do kawałka miary zerowej - zbioru małej tercjany 
w rozkładzie inwestycji i zbioru małej tercjany w rozkładzie dochodów można traktować jako ekonomiczny odpowiednik linii wiecznego śniegu. Jest to współgranie tercjany w rozkładzie dochodów z tercjaną STATYSTYCZNY w rozkładzie inwestycji. Dobrobyt jest subiektywny; wyzbycie się potrzeb zwiększa dobrobyt. Jeśli dobrobyt jest mierzony siłą nabywczą, to dobrobytu nie ma. Dobrobyt można bowiem utożsamiać z pożądanym koszykiem dóbr. Jeżeli ten koszyk się zmienia, to zmienia się i dobrobyt. Taka definicja dobrobytu zależy od wyboru koszyka dóbr, nie ma więc własności inwariantnej. Koszyków jest dużo, nie ma ideału. Oferta handlowa ciągle rośnie, otwierane są nawet sklepy wyłącznie dla milionerów. Wyzbycie się potrzeb to jedyna droga prowadząca do dobrobytu. Wiedział o tym Diogenes, gdy prosił Aleksandra, by nie zasłaniał mu słońca, bo innych już potrzeb nie ma. Zmniejszenie koszyka dóbr zwiększa dobrobyt. „Dziś nie ma potrzeb na mięso" - to popularne powiedzenie z czasów realnego socjalizmu. Dobrobyt może być tylko stabilny. Miecz Damoklesa oznacza, że dobrobyt w ciągłym zagrożeniu staje się swoim zaprzeczeniem. Biedak jest wolny i może się czuć lepiej niż posiadacz. Niedostatek nędzarza jest przykrością, ból duszy bogacza - zgubą. Dobrobyt jako preferencja może być relacją maksymalną. Jeśli obowiązuje reguła $2 / 3$, czyli gdy istnieje prawie powszechna zgoda $\mathrm{w}$ całej populacji, wtedy relacja maksymalna jest preferencją. Reguła $2 / 3$ jest więc warunkiem wystarczającym na to, by relacja maksymalna była preferencją. Dobrobyt może być też średnim koszykiem dóbr. Obydwa wybory są zbliżone, choć wydaje się, że powołanie się na prawo natury, a jest nim reguła 2/3, przeważa na korzyść relacji maksymalnej.

Istnieją próby opisania giełdy wykorzystujące procesy Markowa. Giełda jest błądzeniem losowym o trzech stanach: grupa złych przedsiębiorstw - ich akcje są notowane nisko, grupa średnia - akcje oscylują wokół wartości rynkowej i grupa dobra - akcje zwyżkują. Doświadczenie pokazuje, że przejście firmy ze stanu aktualnego do stanu nowego zależy jedynie od chwili bieżącej, a nie od dalszej przeszłości, w związku z tym giełda jest prostym przykładem łańcucha Markowa. Podobnie sytuacja wygląda ze społeczeństwem podzielonym tercjanami na trzy klasy: biednych, średniozamożnych i bogatych. Macierz przejść

$$
T=\left(\begin{array}{ccc}
\frac{2}{3} & \frac{1}{3} & 0 \\
\frac{1}{6} & \frac{2}{3} & \frac{1}{6} \\
0 & \frac{1}{3} & \frac{2}{3}
\end{array}\right)
$$


jest racjonalnym opisem społeczeństwa. Wiersze i kolumny odpowiadają kolejno: klasie biednych, średniozamożnych i bogatych. W pierwszym wierszu macierzy $T$ dane są prawdopodobieństwa przejścia ze stanu pierwszego - biednych - kolejno do stanów: 1, 2, 3; w drugim wierszu dane są prawdopodobieństwa przejścia ze stanu średniozamożnych, a w trzecim - ze stanu bogatych również do stanów: $1,2,3$. Tylko wszystkie prawdopodobieństwa przejścia ze stanu drugiego są dodatnie. Nie można przejść w jednym kroku ze stanu najniższego do najwyższego i odwrotnie ze stanu bogatych do biednych. Stany te można uważać również za trzy zalecenia analityków giełdowych dla inwestorów: redukuj, trzymaj, kupuj. Redukuj posiadane akcje, bo spodziewany jest spadek, trzymaj - spadku nie będzie, kupuj - zbliża się wzrost. Podane prawdopodobieństwa mierzą siłę zalecenia. Macierz $T$ ma trzy wartości własne: $\sigma_{1}=\frac{1}{3}, \sigma_{2}=\frac{2}{3}$, $\sigma_{3}=1$. Wartości własnej $\sigma_{1}$ odpowiada wektor własny $a_{1}=(1,-1,1)$, wartości $\sigma_{2}$ - wektor $a_{2}=(1,0,-1)$, oraz wartości $\sigma_{3}$ wektor własny $a_{3}=(1,1,1)$.

Macierz

$$
A=\left(\begin{array}{ccc}
1 & 1 & 1 \\
-1 & 0 & 1 \\
1 & -1 & 1
\end{array}\right)
$$

zamienia bazę naturalną: $e_{1}=(1,0,0), e_{2}=(0,1,0)$ i $e_{3}=(0,0,1)$ na bazę złożoną z wektorów własnych: $a_{1}, a_{2}, a_{3}$. W nowej bazie macierz $T$ będzie macierzą diagonalną $S=A^{-1} T A$, gdzie

$$
A^{-1}=\left(\begin{array}{ccc}
\frac{1}{4} & -\frac{1}{2} & \frac{1}{4} \\
\frac{1}{2} & 0 & -\frac{1}{2} \\
\frac{1}{4} & \frac{1}{2} & \frac{1}{4}
\end{array}\right), \quad S=\left(\begin{array}{ccc}
\frac{1}{3} & 0 & 0 \\
0 & \frac{2}{3} & 0 \\
0 & 0 & 1
\end{array}\right) .
$$

Macierz $S$ nie ma interpretacji probabilistycznej lub jest równoważna macierzy Markowa $T$. Jednakże macierz $S$ jest bardzo użyteczna, ponieważ znacznie upraszcza obliczanie macierzy granicznej ciągu $\left(T^{n}\right)$. Ciąg $\left(S^{n}\right)$ ma oczywiście granicę oraz

$$
\lim \left(S^{n}\right)=\left(\begin{array}{ccc}
0 & 0 & 0 \\
0 & 0 & 0 \\
0 & 0 & 1
\end{array}\right),
$$

a ponieważ $T^{n}=A S^{n} A^{-1}$, więc $B=\lim \left(T^{n}\right)=A \lim \left(S^{n}\right) A^{-1}$. Ostatecznie jest więc 


$$
B=\left(\begin{array}{ccc}
\frac{1}{4} & \frac{1}{2} & \frac{1}{4} \\
\frac{1}{4} & \frac{1}{2} & \frac{1}{4} \\
\frac{1}{4} & \frac{1}{2} & \frac{1}{4}
\end{array}\right) .
$$

Wynika stąd, że asymptotycznie stan średni jest uprzywilejowany obejmuje $50 \%$ populacji; w pozostałych stanach jest po $25 \%$. Złoty środek rządzi stabilnym społeczeństwem.

Przyjmuje się, że pokolenie trwa 25 lat, a zmiana swego położenia - przejście z jednej klasy zamożności do innej klasy - możliwe jest średnio raz na 8 lat i 4 miesiące, czyli na $\frac{1}{3}$ pokolenia - pokolenia jako jednostki czasu. W czasie jednego pokolenia mogą więc być tylko trzy zmiany statusu społecznego. Oczywiście można wygrać fortunę lub ją przegrać - to są właśnie zdarzenia losowe. Graniczna macierz Markowa $B$, gdy macierz wyjściowa $T$ oparta jest na regule $2 / 3$, mówi, że stan średniej zamożności jest uprzywilejowany i obejmuje połowę populacji, a pozostałe dwa stany ubogich i bogatych to druga połowa rozdzielona na dwie równe części po $25 \%$ całości każda. Jest to optymalny, wieczny, niezmienny podział populacji ludzkiej. Wychodzi się z reguły $2 / 3$ dzielącej dochody na trzy klasy. Można również mówić o inwestycjach: niskich, średnich i wysokich. Średnio inwestuje połowa populacji: $\frac{1}{4}$ mało inwestuje, $\frac{1}{4}$ dużo. Łatwiej bowiem wydawać niż oszczędzać; enjoy your shopping - nawołują w galeriach handlowych na całym świecie. Puszczanie pieniędzy wiąże się z przyjemnością, a odkładanie - z wyrzeczeniem. Warto zaznaczyć, że chociaż $\frac{2}{3}$ Polaków uważa, że należy oszczędzać, to tylko $\frac{1}{3}$ gospodarstw domowych ma oszczędności [Olechowski 2014]. Warunkiem wzrostu dobrobytu jest zatem wzrost oszczędności. Dobrobyt to nie tylko produkcja i zarobki, lecz także zgromadzony majątek. Majątek przeciętnego Polaka wart jest 21 tys. dolarów, a Szwajcara 407 tys. dolarów. Beati possidentes - błogosławieni majętni. Koroną mądrych jest ich bogactwo (Prov. 14.24). Daleka droga przed nami.

Niewątpliwie alle Theorie ist grau (każda teoria jest szara), lecz prawa nauki są jasne - świecą prawdą wewnętrzną. Prawem nauki jest reguła $2 / 3$.

Zasada porządku społecznego. Jeżeli częstotliwość jest ostro większa od $\frac{1}{3}$, to jest ostro większa od $\frac{2}{3}$. Oznacza to, ze $w$ przedziale ] $\frac{1}{3}, \frac{2}{3}$ ] nie ma czesstotliwości. Stan ten powszechnie występuje pod nazwa opinio communis. Jego wptyw na język codzienny jest przeważajacy. 
Większość kwalifikowana na poziomie $\frac{2}{3}$ nie jest arbitralnie usta-

Nr 13(19)) loną granicą - jedną z możliwych - lecz prawidłowością wyróżniającą preferencję społeczną. Definicja przyrodnicza liczby $\frac{2}{3}$ jest tej samej natury, co liczby $\pi$, liczby $e$ i innych fundamentalnych stałych fizycznych. Relacja większościowa jest preferencją zawsze wtedy, gdy każda jej alternatywa ma w profilu częstotliwość silnie większą od $\frac{2}{3}$. Many subjects make a famous king; with none to rule a prince is ruined (Prov. 14.28).

Macierz Markowa

$$
M=\left(\begin{array}{ccc}
\frac{2}{3} & \frac{1}{3} & 0 \\
\frac{1}{3} & \frac{1}{3} & \frac{1}{3} \\
0 & \frac{1}{3} & \frac{2}{3}
\end{array}\right)
$$

powstaje z macierzy $T$ przez lekką korektę wiersza drugiego. Ta niewielka zmiana ilościowa prowadzi do zmiany jakości procesu. Przypuszczalnie $M$, ze względu na symetrię, lepiej oddaje naturę zachowań ludzkich niż $T$. Spektrum macierzy $M$ jest trójelementowym zbiorem,

$$
\operatorname{sp} M=\left\{0, \frac{2}{3}, 1\right\},
$$

a macierz asymptotyczna $\lim \left(M^{n}\right)$, wyrachowana analogicznie jak macierz $B$ z macierzy $T$, ma wszystkie wyrazy równe. Przejście z każdego stanu do każdego innego jest równoprawdopodobne; w każdym stanie jest $\frac{1}{3}$ populacji. Niezależnie od tego, gdzie byłem na początku, po dostatecznie długim błądzeniu, z jednakowym prawdopodobieństwem mogę się znaleźć wszędzie. Oznacza to maksymalną entropię żyjemy w świecie niepewnym: dziś jestem na górze, a za chwilę mogę zniżkować. Ten właśnie wniosek filozoficzny wypływający z modelu $M$ czyni go niemal prawem nauki - prawem powszechnej równości i sprawiedliwości, prawem równowagi. Nie ma uprzywilejowanych, kondycja każdego jest tak samo niepewna: sprawiedliwy przypadek rządzi światem. Czy jest to przypadek? Stany skrajne tylko z początku mają się lepiej - silniej przyciągają. Ostatecznie jest demokracja - nie ma biedy, nie ma też luksusu. Toczy się koło fortuny. Biedni będą zawsze, w związku z tym aby zwalczyć biedę potrzeba najpierw zlikwidować bogactwo. Jeśli jest bogactwo, a więc dobro w ograniczonym rozmiarze, to zawsze będzie mu towarzyszyć bieda. Bogactwo równomiernie rozłożone $\mathrm{w}$ populacji ma zadziwiającą cechę: skupiania się w wybranych punktach - jak materia w przestrzeni kosmicznej. 
Równość jest iluzją: podobnie jak w przyrodzie każdy liść jest inny, tak każdy człowiek ma sobie tylko właściwe preferencje. To jest powodem generycznej nierówności - biedy różnie rozumianej. W trakcie pisania artykułu w otoczeniu autorów przeprowadzono ankietę; zapytano 13 osób o wysokość miesięcznych dochodów netto na członka rodziny, które już gwarantują dobrobyt. Tylko jedna osoba uchyliła się od odpowiedzi, pisząc nie potrafię z wielkim pytajnikiem; pozostałe podały niezależne przypuszczalnie szacunki, w jednym przypadku jest to przedział. Mamy więc 12 realizacji zmiennej losowej mianowanej złoty na miesiąc: 1500, 2500, 3000, 3500, 4000, 4000, 4000, [4000-5000], 5000, 5000, 6000, 20000. Wielkość ta zależy od obecnego stanu finansowego pytanego. Młodzi na dorobku podawali wyższe kwoty niż starsi; ukierunkowani na życie duchowe - niższe od tych widzących dobrobyt w dobrach materialnych i konsumpcji. Graniczny rozkład pieniężnej miary dobrobytu ma modę równą 4000; średnia 5250 jest znacznie oddalona od mody. W obliczeniach średniej przedział zastąpiono jego środkiem. Przynajmniej dwie osoby uważają swoje rodziny za żyjące w dobrobycie; w tych rodzinach rzeczywista średnia jest wyższa od podanej w ankiecie.

Koncentracja kapitału napędza rozwój. Bogactwo ponad miarę ludzkich potrzeb nie jest zbędne. Kapitał jest dobrem pożądanym jako źródło wzrostu wydajności, rozwoju infrastruktury, mecenatu artystycznego i naukowego. Pogoń za milionami i miliardami jest natury wyczynu sportowego. Innymi motywami kierujemy się, gdy zarabiamy na życie, a innymi gdy gromadzimy wielki kapitał [Staszewski 2014]. W tym drugim przypadku pracujemy nie $\mathrm{z}$ powodu głodu i chłodu, lecz z chęcią bycia lepszymi wśród równie bogatych. Jest to gra dla przyjemności wygrania. Na tym hobby zyskują wszyscy większy kapitał, większa wydajność. Zbiór jagód na określonym obszarze jest prostym modelem życia społecznego: współzawodnictwo w ilości i jakości. Milionerzy ścigają się w wysokości dochodów, podobnie jak przy każdej pracy mierzonej ilością: $\frac{1}{3}$ zbierze dużo, $\frac{1}{3}$ średnio i $\frac{1}{3}$ mało. Decyduje organizacja pracy i sprawność fizyczna. Tak samo zbiera się miliony jak jagody. Podstawą dobrobytu jest tradycja; bez ustalonej struktury społecznej i zawodowej, bez silnych związków grupowych nie ma dobrobytu, bo dobrobyt to sprawne funkcjonowanie organizmu społecznego, bez eksperymentów i nowinkarstwa. Stowarzyszenia pomocy sąsiedzkiej - znane w Anglii od lat neighbourhood guilds, w Polsce czymś takim była instytucja tłoki - przyczyniają się do niwelacji skazy rozproszonego kapitału i podno- 
szą dobrobyt grupy. Dobrobyt jest kategorią społeczną: szukamy partnerów na wieczór, imprezujemy grupowo; przykład działa - pochłaniamy tony narkotycznej żywności: im więcej jesz, tym większy apetyt. Raz jeszcze pojawia się tu równanie Malthusa. Zapominamy, że temperantia jest cnotą. Lubimy żyć chwilą i cieszyć się powszechnym dostatkiem, który niesie wydajna technologia; upojne życie jest gwarantowane przez zautomatyzowany przemysł.

\section{Trunkowa industria}

\section{Miody syć! - Warz piwo! \\ Gorzatkę pędź! - Rób wino!}

Przemysł spożywczy uszczęśliwia, a wydatnie wspomaga go health industry dający $\mathrm{w}$ dużym procencie namiastki narkotyków. Walka o byt słabnie w miarę wzrostu wydajności - ludzie stają się lepsi, mają czas na odpoczynek i refleksję. Bliźni staje się towarzyszem i pomocnikiem, a nie konkurentem. Oby media dały nam również czas wolny! Chleba i igrzysk mamy w nadmiarze. „Zabójcza i zakłamana medycyna" - pod takimi nagłówkami krzyczy prasa o nowej patologii społecznej, jaką jest właśnie health industry. Koncerny farmaceutyczne prostytuują lekarzy. Najwięcej chorych umiera z powodu serca, raka i leków - w tej dokładnie kolejności. Dzisiejsza farmakologia jest zdradą i zaprzeczeniem idei Paracelsa. Koncerny popełniają czyny karalne; biznes jatrochemiczny stał się zorganizowanym przestępstwem korupcją na wielką skalę i wpychaniem ciemnoty [Internet 2014; Patora 2014]. Miliony starców poruszających się na wózkach lub przy pomocy balkoników - to prawdziwa miara sukcesu dzisiejszej medycyny. Już zapomnieliśmy, że lepiej być przez rok orłem niż żyć 10 lat padalcem.

Naturalnie nie dla każdej macierzy Markowa $U$ istnieje macierz graniczna $\lim \left(U^{n}\right)$. Jeżeli wartość własna macierzy Markowa jest liczbą zespoloną o module 1 lub większym, to macierz graniczna nie istnieje.

Uwaga. Jeżeli $\alpha^{2}+\beta^{2}=1$, to macierz zespolona

$$
\left(\begin{array}{cc}
\alpha-\beta i & 0 \\
0 & \alpha+\beta i
\end{array}\right)
$$

jest równoważna nad ciałem liczb zespolonych macierzy rzeczywistej

$$
\left(\begin{array}{cc}
\alpha & -\beta \\
\beta & \alpha
\end{array}\right)
$$


reprezentującej obrót płaszczyzny. Superpozycje obrotów nie stabilizuja się-pomijamy naturalnie tożsamość.

Preferencje to relacje zwrotne i przechodnie. Jakość jest preferencją - pewnie tą najważniejszą. Każda preferencja jest swego rodzaju iloczynem porządku i równoważności: utożsamienie obiektów równoważnych czyni $\mathrm{z}$ preferencji porządek. W dalszym ciągu mówimy o preferencjach liniowych - relacjach waloryzujących każde dwa elementy ustalonego zbioru towarów $X$; zamiast o dobrach materialnych można myśleć o kandydatach na określone stanowisko. Jeżeli $K=\{0$, $\ldots, n\}$ oznacza skończony, $n+1$ elementowy zbiór nabywców lub wyborców, to układ $\left(p_{0}, \ldots, p_{n}\right)$ preferencji, gdzie $p_{i}$ jest liniową preferencją $i$-tego klienta, nazywa się profilem. Elementy produktu $X \times X$, czyli pary towarów $(x, y)$, są alternatywami lub decyzjami. Jeżeli $p$ jest preferencją liniową, to naturalnie $(x, y) \in p$ lub $(y, x) \in p$, czyli xpy lub ypx. Relacja maksymalna $m$, określona profilem $\left(p_{0}, \ldots, p_{n}\right)$, oznaczana też symbolem $m\left(p_{0}, \ldots, p_{n}\right)$, spełnia warunek: $x m y$ wtedy i tylko wtedy, gdy zbiór $\left\{i \in\{0, \ldots, n\}: y p_{i} x\right\}$ jest równoliczny z podzbiorem zbioru $\left\{i \in\{0, \ldots, n\}: x p_{i} y\right\}$. Relacja maksymalna jest większością absolutną. Jeżeli więc $x m y$, to alternatywa $(x, y)$ ma więcej zwolenników niż $(y, x)$, chyba że jednocześnie $y m x$, wtedy obie alternatywy są równoważne. Większość kwalifikowana na poziomie $50 \%$ jest nieco inną relacją $k$. Jeżeli $x k y$, to alternatywa $(x, y)$ ma przynajmniej $50 \%$ zwolenników. Relacja $s$ spełnia regułę $2 / 3$, jeżeli $x s y$ i alternatywa $(x, y)$ ma w profilu $\left(p_{0}, \ldots, p_{n}\right)$ więcej - silnie więcej - niż $\frac{2}{3}$ zwolenników. Twierdzenie Janusza Łyki mówi, że gdy relacja spełnia regułę $2 / 3$, to $m$ jest preferencją [Łyko 2000]. Większość kwalifikowana na poziomie $\frac{1}{2}$ jest słabszą relacją. Jeżeli $m$ spełnia regułę $2 / 3$, to $k$ może jej już nie spełniać, ale gdy $k$ spełnia regułę $2 / 3$, to naturalnie spełnia ją i $m$. Jeżeli wszystkie preferencje w profilu są porządkami, to $m=k$. W ogólnym przypadku wyróżnia się dwie relacje społeczne $m$ i $k$-większość absolutną $m$ i większość kwalifikowaną $k$ na poziomie $50 \%$. Jeżeli $m$ i $k$ są preferencjami, to relacja $m$ jest bliższa relacji porządku niż $k$. Oznacza to, że jest mniej liczną relacją - mniej obiektów zostaje utożsamionych przy dzieleniu przez równoważność. Podstawą twierdzenia Łyki jest fundamentalny lemat forsujący.

Forcing stochastyczny. Jeżeli prawdopodobieństwo zdarzenia A jest $w$ przedziale $\left.] \frac{2}{3}, 1\right]$ i prawdopodobieństwo zdarzenia $B$ jest równiez $w$ tym przedziale, to prawdopodobieństwo zdarzenia $A$ i $B$ jest $w$ przedziale $\left.] \frac{1}{3}, 1\right]$. 
PRZEGLĄD STATYSTYCZNY

Nr 13(19))

Nie ma dobrobytu bez równowagi i pełnego zatrudnienia. Najprostszym miernikiem trwałego dobrobytu jest indeks

$$
W=\frac{n}{k+n},
$$

gdzie $n$ oznacza liczbę firm nowych powstałych w danym roku, a $k$ zlikwidowanych. Oczywiście $k, n \in N$ oraz $k+n>0$. Jeżeli $k+n=0$, to stan jest idealny - pełne zatrudnienie i harmonijny rozwój, lub całkowity zastój - wielkie i bezrobocie i chaos organizacyjny. Im ten wskaźnik jest bliższy jedności tym lepiej. Wielkość $W$ jest dalekim echem czasów grynderskich. Gründerzeit charakteryzuje się wartością $1 / 2$ wskaźnika $W$. Miernik $W$ jest liczbą wymierną z przedziału $[0,1]$. Dobrobyt to w żadnym wypadku nie pełnia władzy, pieniądza i użycia. Dobrobyt to stan duszy, a nie ciała. Jest funkcją organizacji i samoorganizacji, jest odmianą stoicyzmu.

Dobrobyt konotuje się globalnie, czyli dotyczy całego społeczeństwa. Trudno mówić o dobrobycie wybranych jednostek w morzu biedy. Stąd pojęcie państwa dobrobytu - welfare state - i ekonomii dobrobytu. Sprawiedliwość społeczna, rozumiana jako równomierny podział bogactwa, obniża dobrobyt. Przy równomiernym podziale wszyscy muszą inwestować $8 \%$, a nawet więcej. Bez inwestycji wydajność nie rośnie, nie ma postępu. Obecnie najbiedniejsi żyją na poziomie bogatych z X wieku. Lubimy podnosić swój statut społeczny. Częściej mówimy o życiu w dobrobycie własnej rodziny, niż o ubóstwie. To sąsiedzi klepią biedę. Dobrobyt jest oczywiście stanem subiektywnym i relatywnym, względnym, co poświadcza bajka o rybaku i złotej rybce. Najpierw wystarcza kawałek słoniny, a później pałac ze służbą to już za mało; musi dojść do katastrofy. Człowiek chce być Bogiem.

\section{Literatura}

Biernacki M., Dobrobyt, [w:] J. Łyko (red.), Wybrane modele matematyczne w ekonomii, Wydawnictwo Uniwersytetu Ekonomicznego we Wrocławiu, Wrocław 2009, s. 55-95.

Dębek K., Życie, „Gazeta Południowa” 2014, 17 września, s. 2.

Internet, Zabójcza i zakłamana medycyna, „Angora” 2014, 30 listopada, s. 75.

Łyko J., Twierdzenia Arrowa a ordynacje wyborcze, [w:] A. Smoluk (red.), Elementy metrologii ekonomicznej, Wydawnictwo Akademii Ekonomicznej we Wrocławiu, Wrocław 2000, s. 165-168.

Olechowski J., Polacy (nie) oszczędni? „Newsweek Polska” 2014, 21 lipca, s. 70-71.

Patora T., Tu starości nie leczymy, „Angora” 2014, 23 listopada, s. 28-29.

Staszewski W., Życie codzienne milionerów, „Newsweek Polska” 2014, 28 lipca, s. 36-38. 


\section{AN ATTEMPT OF THE FORMAL DEFINITION OF WELL-BEING}

Summary: Well-being is a quality, and each quality has three natural states: a little, moderately, a lot. Well-being resembles happiness and health. When we have well-being, we usually are not aware of it. Certainly, we all want to live a life of well-being. While we do not specify the notion of happiness so as to avoid bad luck and not to show off with it, we do not define well-being either. It is a blessed state of existing together with nature and with people. Permanent well-being is equated with stable well-being. It is achievable only in a traditional society, where everyone knows what to do and gets it done as expected. Well-being also is associated with social Darwinism; population has well-being when it grows exponentially. Malthusian equation

$$
y^{\prime}=p y
$$

can be seen as a precise definition of well-being. Well-being is a holistic term that applies to a whole community as the quality of life, often equivalent to standard of living. There is no well-being on a desert island. Well-being implies work productiveness and indicates that economy is more efficient than social needs. Well-being may also be expressed by utility functions. Population's average utility defines social well-being. Each utility function is linked to preference. If a population's profile satisfies the $2 / 3$ rule, then a maximal relation is preference; in fact, the very preference is social well-being. Stability of wellbeing in Markov matrix

$$
M=\left(\begin{array}{lll}
\frac{2}{3} & \frac{1}{3} & 0 \\
\frac{1}{3} & \frac{1}{3} & \frac{1}{3} \\
0 & \frac{1}{3} & \frac{2}{3}
\end{array}\right)
$$

is represented by transitions from the states: low being, being and good being, respectively, to these states. If the probabilities of transitions are as those in the matrix $M$, then the population is divided into three equal parts at a limit state. There are always poor people, normal or happy people and rich people. Well-being may also stand for a state of the economy - a basket of goods at which the utility function takes the maximum. Well-being is definitely related to work organization and economic situation. The world today enjoys well-being, because the net global wealth has doubled since 2000, reaching \$263 trillion in 2013. The assets therefore increased exponentially. Yet, one should consider the lilies of the field, and how they grow, look at the birds of the air and think about who feeds them. The idea of wellbeing is more spiritual than material. It is in vain that you go late to rest and get up early your effort will not gain much. Because God gives sleep to those he loves.

Life is the only value affirmed by Nietzsche. Being represents a complete good, whereas not being is evil. If you exist, you have well-being. There is no well-being without equilibrium and full employment. Well-being can be measured by an index

$$
W=\frac{n}{k+n}
$$

where $n$ denotes the number of new firms established in a given year, and $k$ - the number of closed firms. The nearer to one is this index, the better. Well-being is by no means total power, fortune and pleasure. Well-being is a state of soul, not a state of body. It is a function of organization and self-organization, a variety of stoicism.

Keywords: state of welfare, 2/3 rule, utylity functions, Malthus' increase, Markov's matrix. 